\title{
Sustainability Assessment of Enterprises in Printing Industry
}

\author{
Loreta Kinderyte \\ Institute of Environmental Engineering, Kaunas University of Technology
}

crossref $\mathrm{http}: / / \mathrm{dx}$.doi.org/10.5755/j01.erem.58.4.674

(received in September, 2011, accepted in December, 2011)

\begin{abstract}
A sustainability concept having been applied from global to national, regional and other levels, enterprises are striving to be more sustainable in environmental and social issues. There is a growing need to have sustainability assessment and implementation tools. The most popular is the Global Reporting Initiative which gives recommendations for sustainability assessment of enterprises in different sectors. The guidelines are prepared for logistics and transportation, financial services, mining and metals, telecommunication and the others but not yet for printing industry. The objective of the paper is to assess sustainability of printing enterprises. To achieve it the following tasks have been determined: 1) adopt sustainability assessment methodology to printing industry; 2) apply sustainability assessment to chosen printing enterprises and 3) suggest the measures for sustainable development of printing enterprises. A sustainability assessment system is developed and applied which consists of qualitative and quantitative parts and composite index. Qualitative and quantitative parts are aggregated into one improved sustainability index. Enterprises are rated according to their achievements in sustainability from unsustainable through basic to progressive sustainable enterprises. The sustainability indices show that enterprises are at the basic level of sustainability. The main areas for improvement in printing enterprises are the following: use of more ecologic paper, paints and other resources; reduction of volatile organic compounds, use of renewable energy, etc. The case of an applied sustainability assessment system has shown that it can be adapted to enterprises of other sectors.

Keywords: sustainability assessment, sustainability indicators, enterprise sustainability index, sustainability in printing enterprise, qualitative and quantitative assessment.
\end{abstract}

\section{Introduction}

Sustainable development of an enterprise is defined as "adopting business strategies and activities that meet the needs of the enterprise and its stakeholders today while protecting, sustaining and enhancing the human and natural resources that will be needed in the future"' (Deloitte and Touche 1992). Sustainability assessment tools are used for distinguishing the most sustainable or socially responsible enterprise for communication of sustainability performance (reporting) (Székely et al. 2005). There are some methodologies widely used in practice like Global Reporting Initiative (GRI) for reporting, Dow Jones Sustainability Index for enterprise rating. A lack of standardized metrics or performance benchmarks is the fourth potential barrier to sustainability for enterprise (AMA 2007). In order not only to evaluate the progress towards sustainability but to give directions for the future the need for such complex assessment tools still exists.

This study concentrates on help for enterprises to achieve better sustainability because sustainability assessment models lack guidance on how an enterprise can become more sustainable. Assessment gives the evaluation but not the solutions. The task of this study is to integrate various tools into sustainability assessment model.

In assessing sustainability some criteria are difficult to be evaluated in quantitative units therefore qualitative information should be included (Székely et al. 2005, Diakaki et al. 2006, Veleva and Ellenbecker 2000). Sustainability assessment methodology has been developed including not only quantitative but qualitative aspects of sustainability (Kinderytė 2010, Staniškis and Arbačiauskas 2009). 
An objective of this research is to apply sustainability performance methodology to enterprises of a selected sector. As printing industry has been little analyzed from the sustainable development point it is chosen for this study.

This target is split into tasks: 1) to apply sustainability assessment methodology to enterprises of a printing sector, 2) to include guidance to actions and measures in sustainability assessment, 3) to evaluate sustainability of a selected enterprise in printing industry.

\section{Methods}

A qualitative-quantitative sustainability assessment model (Kinderytė et al. 2010) is chosen as a base for this research to make it more oriented to practical improvement of enterprise's sustainability. This model is used for assessment of industrial enterprises.

Sustainability assessment consists of the following main steps based on Deming cycle: planning of performance evaluation, handling and use of data and information, performance assessment review and improvement (Kinderytė et al. 2010). A qualitative sustainability checklist is created using experts' survey (Kinderytė 2010, Kinderytè et al. 2010) for identification and assessment of qualitative indicators. The qualitative assessment is universal to any industrial enterprise. Indicators for quantitative assessment determined by experts should be adjusted to a certain industry sector.

A set of indicators consists of 20 qualitative indicators selected by experts and 24 quantitative indicators which were adapted to printing industry. Qualitative and quantitative indicators are distributed to economical, social and environmental parts of sustainability accordingly:

- Economical: general economical indicators, indicators of indirect economic impacts.

- Social: occupational health and safety, human capital development, communication with stakeholders.

- Environmental: eco-design, pollution prevention, use of resources and energy, effluents and waste, product responsibility, environmental costs.

A three levels scale is used for qualitative assessment: the worst evaluation is 0 , the medium evaluation -0.5 and the best evaluation -1 (Table 1 ).

A set of quantitative indicators of the environmental part based on research studies is used in the printing sector.

For aggregation of qualitative and quantitative information the method of composite index is applied. Aggregate information in an index helps to make decisions about the level of enterprise's sustainability. (Kinderyte et al. 2010). For building a composite index the following steps are carried out: selection of indicators, normalization, weighting of indicators, aggregation, sensitivity analysis, interpretation (Nardo et al. 2005, OECD 2008).

Table 1. Example of qualitative assessment (Kinderyte 2010)

\begin{tabular}{||c|l|c|}
\hline Indicator & \multicolumn{1}{|c|}{ Values of an indicator } & Assessment \\
\hline $\begin{array}{c}\text { Use of } \\
\text { renewabl } \\
\text { e energy }\end{array}$ & $\begin{array}{l}\text { Renewable energy is not } \\
\text { considered }\end{array}$ & 0 \\
\cline { 2 - 3 } & $\begin{array}{l}\text { Renewable energy is } \\
\text { considered partly }\end{array}$ & 0.5 \\
\cline { 2 - 3 } & $\begin{array}{l}\text { Enterprise produces or } \\
\text { buys all required energy } \\
\text { from regenerative sources }\end{array}$ & 1.0 \\
\hline
\end{tabular}

For normalization of quantitative indicators the Min-Max method is chosen resulting in an identical range $[0,1]$. The normalized value is achieved by subtracting the minimum value and dividing the remainder by the range of the indicator values. Quantitative indicators have been normalized according to the formulas (OECD, 2008; Krajnc et al., 2005):

$I_{N, i j t}^{+}=\frac{I_{A, i j t}^{+}-I_{\min , j t}^{+}}{I_{\max , j t}^{+}-I_{\min , j t}^{+}}$

Where:

$I_{A}^{+}-\quad$ indicator whose increasing value has a positive impact in the perspective of sustainability;

$I_{\text {min }}^{+}-\quad$ indicator with minimum value and positive impact on sustainability;

$I_{\max }^{+}-\quad$ indicator with maximum value and positive impact on sustainability;

$I_{N}^{+}-\quad$ normalized indicator whose increasing value has positive impact on sustainability;

$\begin{array}{ll}\mathrm{i}- & \text { sustainable development indicator; } \\ \mathrm{j}- & \text { group of sustainable development }\end{array}$ indicators: economical, social and environmental, $\mathrm{t}$ - time in years.

$I_{N, i j t}^{-}=\frac{I_{\max , i j t}^{-}-I_{A, j t}^{-}}{I_{\max , j t}^{-}-I_{\min , j t}^{-}}$

Where:

$I_{A}^{-}-\quad$ indicator whose increasing value has negative impact in the perspective of sustainability,

$I_{\text {min }}^{-}-\quad$ indicator with minimum value and negative impact on sustainability,

$I_{\max }^{-}-$indicator with maximum value and negative impact on sustainability,

$I_{N}^{-}-$normalized indicator whose increasing value has a negative impact on sustainability. 
Experts' survey as a method was applied to assign weighting coefficients to indicators (Kinderyte et al. 2010, Kinderytė 2010). The same weighting coefficients were used for printing enterprises. Simple additive weighting was used as a method to aggregate weighted indicators into an index.

One new part was added to the sustainability assessment model and index (Kinderyte et al. 2010) the level of actions towards sustainable development of the environmental part of a printing enterprise. To develop this toolbox the best available techniques in printing industry (BREF STS 2007) and industrial ecology principles were applied.

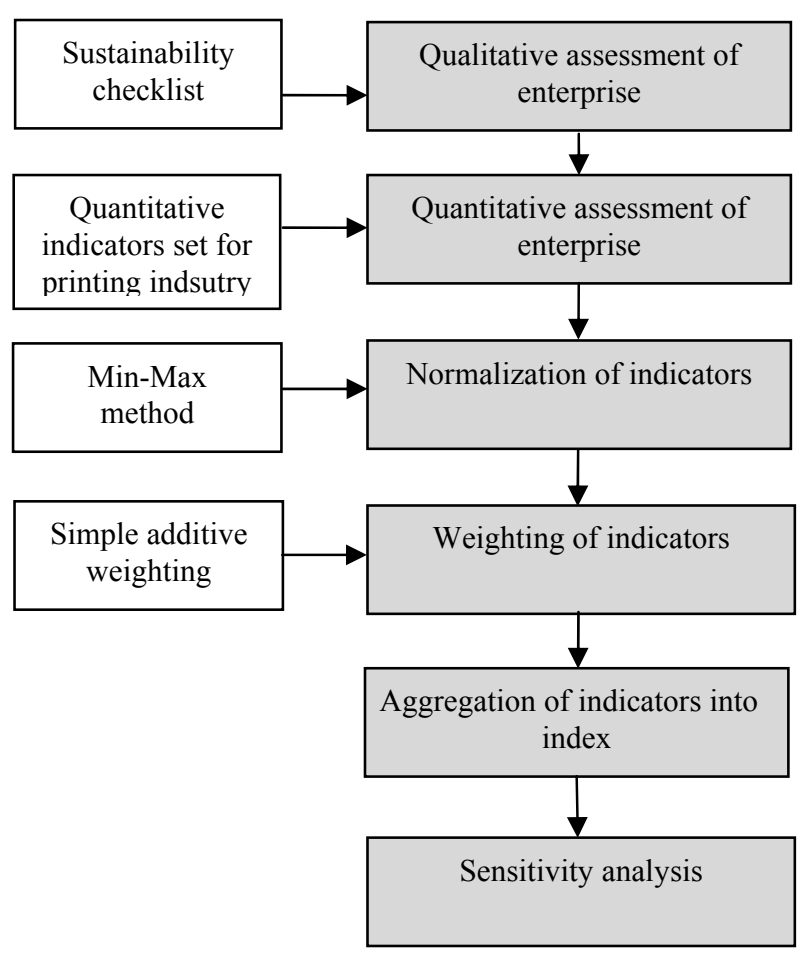

Fig. $1 \quad$ Calculation of composite index

Enterprise sustainability index $\left(\mathrm{I}_{\mathrm{ESI}}\right)$ consists of three sub-indices: qualitative assessment ( $\left.\mathrm{I}_{\text {qual }}\right)$, quantitative assessment $\left(\mathrm{I}_{\text {quan }}\right)$ and level of actions taken towards sustainable development $\left(\mathrm{I}_{\text {actions }}\right)$ :

$\mathrm{I}_{\mathrm{ESI}}=\mathrm{I}_{\text {qual }}+\mathrm{I}_{\text {quant }}+\mathrm{I}_{\text {actions }}$

The level of sustainability is defined according to the value of enterprise sustainability index calculated: 0-0.33 - unsustainable enterprise, 0.340.66 - sustainable enterprise at the basic level, 0.67-1 - sustainably progressive enterprise (Kinderyte et al. 2010).

\section{Research}

Three small Lithuanian enterprises in offset printing industry have been chosen for research. Enterprises possess the certified quality (ISO 9001), environmental management (14001, EMAS) systems.
Table 2. Ranges of environmental quantitative indicators ( $w_{i}-$ weighting coefficient)

\begin{tabular}{|c|c|c|c|}
\hline No & Indicator & $\begin{array}{c}\text { Range } \\
\left(\mathrm{I}_{\min }-\mathrm{I}_{\max }\right) \\
\end{array}$ & $\mathrm{w}_{\mathrm{i}}$ \\
\hline 1. & $\begin{array}{l}\text { Direct energy } \\
\text { consumption }\end{array}$ & $\begin{array}{l}0.24-2.40 \\
\mathrm{MWh} / \mathrm{fu}\end{array}$ & 0.08 \\
\hline 2. & Paper consumption & $\begin{array}{l}1030-1470 \\
\mathrm{~kg} / \mathrm{fu}\end{array}$ & \multirow[t]{5}{*}{0.09} \\
\hline 3. & $\begin{array}{l}\text { Consumption of } \\
\text { plate development } \\
\text { chemicals }\end{array}$ & $0.8-9.7 \mathrm{~kg} / \mathrm{fu}$ & \\
\hline 4. & $\begin{array}{l}\text { Ink and lacquer } \\
\text { consumption }\end{array}$ & $1.8-26.5 \mathrm{~kg} / \mathrm{fu}$ & \\
\hline 5. & $\begin{array}{l}\text { Adhesives } \\
\text { consumption }\end{array}$ & $\begin{array}{l}0.067-1.44 \\
\mathrm{~kg} / \mathrm{fu}\end{array}$ & \\
\hline 6. & $\begin{array}{l}\text { Consumption of } \\
\text { additional chemicals }\end{array}$ & $\begin{array}{l}0.079-10.6 \\
\mathrm{~kg} / \mathrm{fu}\end{array}$ & \\
\hline 7. & Water consumption & $\begin{array}{l}385-2690 \\
\mathrm{~m}^{3} / \mathrm{fu}\end{array}$ & 0.08 \\
\hline 8. & VOC release & $2.5-9.1 \mathrm{~kg} / \mathrm{fu}$ & 0.09 \\
\hline 9. & Paper waste & $17-41 \%$ & \multirow[t]{3}{*}{0.10} \\
\hline 10. & Total waste & $200-390 \mathrm{~kg} / \mathrm{fu}$ & \\
\hline 11. & Waste to landfill & $64-168 \mathrm{~kg} / \mathrm{fu}$ & \\
\hline 12. & Hazardous waste & $9-44 \mathrm{~kg} / \mathrm{fu}$ & 0.08 \\
\hline 13. & $\begin{array}{l}\text { Environmental } \\
\text { accidents }\end{array}$ & $\begin{array}{l}(0-\text { one and } \\
\text { more accidents }\end{array}$ & 0.09 \\
\hline 14. & Take back packaging & $0-100 \%$ & 0.09 \\
\hline 15. & $\begin{array}{l}\text { Consumption of eco- } \\
\text { labeled paper }\end{array}$ & $0-100 \%$ & 0.06 \\
\hline 16. & Environmental costs & $0-2 \mathrm{EUR} / \mathrm{t}$ & 0.06 \\
\hline
\end{tabular}

The names of enterprises are confidential:

Enterprise A produces promotional, corporate style printing, books, journals, maps, etc. The printing house has about 30 employees.

Enterprise B produces softcover books of various sizes and cover decorations and has about 60 employees. In addition to ISO 9001 and ISO 14001 certificates, enterprise B possesses FSC and PEFC to ensure the use of paper from responsibly handled forests.

Enterprise C with 65 employees specializes in production of cardboard packaging for food, pharmaceutical products, industrial and other goods.

Research has been carried out based on 2010 results provided by enterprises.

Qualitative, quantitative and actions' assessments of their development have been done according to the sustainability principles for three enterprises.

A set of quantitative indicators in an environmental part only was adapted to the printing sector (Table 2) based on the research studies (Viluksela 2009, Enroth 2006, Pohjola 2005, Envirovise 2004). These sources (for $1-9$ indicators) and the information from $\mathrm{A}, \mathrm{B}$, and $\mathrm{C}$ printing enterprises (for $10-16$ indicators) helped to build the ranges for quantitative indicators (Table 2). Borders of a range are minimal and maximum values from the 
above mentioned sources. Weighting coefficients remain the same for indicators' groups, like it was defined by experts without consideration of sectors. For example, resources consumption was defined as single indicators but for printing industry it was split into more detailed indicators: consumption of paper, plate development, ink and lacquer, adhesive, additional chemicals. All of the mentioned indicators have one and the same weighting coefficient.

Differently from research studies about printing industry BREF (2007) suggests to use VOC of ink weight (wt-\%). Indicator eco-labelled paper means FSC, recycled and with eco signs marked paper.

\section{Results and Discussion}

A toolbox for actions' assessment was developed to give possible measures to an enterprise for improvement of their environmental sustainability (Table 3). IPPC is not applicable to $\mathrm{A}, \mathrm{B}$ and $\mathrm{C}$ enterprises only for comparison with the best available practice. Only enterprise $B$ meets the requirements of BAT for volatile organic compounds.

$\mathrm{A}, \mathrm{B}$ and $\mathrm{C}$ enterprises use chemicals which can be toxic to aquatic organisms (risk phrases R50/53) and any discharge to surface water should be prevented. Printing enterprises use solvents for dampening solution. Regeneration of used solvents is not considered in industrial practice of enterprises.

Table 3. Toolbox for more sustainable development of enterprise ( $V$-value of normalization)

\begin{tabular}{|c|c|c|c|c|}
\hline \multirow{2}{*}{$\begin{array}{l}\text { Environmental } \\
\text { protection directions }\end{array}$} & \multirow{2}{*}{ BAT and other measures } & \multicolumn{3}{|c|}{ Enterprise } \\
\hline & & $\mathbf{A}$ & B & $\mathbf{C}$ \\
\hline $\begin{array}{l}\text { Release of volatile } \\
\text { organic compounds } \\
\text { VOC }\end{array}$ & $\begin{array}{l}\text { For new or upgraded presses } 2.5-10 \% \text { VOC of } \\
\text { ink weight }(w t-\%)(V=1) \\
\text { For existing presses, } 5-15 \% \text { VOC of ink weight } \\
(\text { wt- } \%)(\mathrm{V}=0,5) \\
>15 \% \text { VOC of ink weight }(\mathrm{V}=0)\end{array}$ & $\begin{array}{c}0.5 \\
(\mathrm{wt}= \\
31.0 \%)\end{array}$ & $\begin{array}{c}0 \\
(\mathrm{wt}= \\
11.0 \%)\end{array}$ & $\begin{array}{c}0 \\
(\mathrm{wt}= \\
23.2 \%)\end{array}$ \\
\hline $\begin{array}{l}\text { Use of hazardous } \\
\text { substances }\end{array}$ & $\begin{array}{l}\text { Chemicals without risk phrases }(\mathrm{V}=1) \\
\text { Hazardous chemicals (risk phrases: } \mathrm{R} 58, \mathrm{R} 50 / 53 \text {, } \\
\text { R59 etc.) }(\mathrm{V}=0,5) \\
\text { Highly hazardous chemicals (risk phrases: R40, } \\
\text { R45, R46, R49, R60, R61 etc.) }(\mathrm{V}=0)\end{array}$ & $\begin{array}{c}0.5 \\
(\mathrm{R} 50 / 53)\end{array}$ & $\begin{array}{c}0.5 \\
(\mathrm{R} 50 / 53)\end{array}$ & $\begin{array}{c}0.5 \\
(\mathrm{R} 50 / 53)\end{array}$ \\
\hline $\begin{array}{l}\text { Regeneration of used } \\
\text { solvents and } \\
\text { secondary use }\end{array}$ & $\begin{array}{l}\text { - Regeneration is not used }(\mathrm{V}=0) \\
\text { - Regeneration is used }(\mathrm{V}=1)\end{array}$ & 0 & 0 & 0 \\
\hline Use of water & Use of rainwater & 0 & 0 & 0 \\
\hline $\begin{array}{l}\text { Use of renewable } \\
\text { energy sources }\end{array}$ & $\begin{array}{l}\text { - Agreement with energy supplier having } \\
\text { renewable energy sources }(\mathrm{V}=0.5) \\
\text { - Investment into renewable energy project }(\mathrm{V}=1)\end{array}$ & 0 & 0.5 & 0 \\
\hline $\begin{array}{l}\text { Use of environmentally } \\
\text { preferable paper: FSC, } \\
\text { recycled or } \\
\text { ecolabelled }\end{array}$ & $\begin{array}{l}\text { - Customers are informed about possibility to } \\
\text { choose environmental preferable paper but it } \\
\text { causes additional cots }(\mathrm{V}=0.5) \\
\text { - Environmentally preferable paper is used for all } \\
\text { printing products }(\mathrm{V}=1)\end{array}$ & 0.5 & 0.5 & 0.5 \\
\hline Use of ecological inks & $\begin{array}{l}\text { - Customers are informed about possibility to } \\
\text { choose environmental preferable inks but it } \\
\text { causes additional cots }(\mathrm{V}=0.5) \\
\text { - Environmentally preferable inks are used for all } \\
\text { printing products }(\mathrm{V}=1)\end{array}$ & 0.5 & 0.5 & 0.5 \\
\hline \multicolumn{2}{|c|}{ Aggregated environmental subindex (average $=$ sum of $\mathrm{V} / 7$ ) } & $\mathbf{0 , 3 6}$ & $\mathbf{0 , 2 9}$ & $\mathbf{0 , 2 1}$ \\
\hline
\end{tabular}

All printing enterprises do not have possibility to use renewable energy. With introduction of environmental management systems the enterprises pay more attention for their suppliers. Enterprise B has made an agreement with supplier which produces electricity partly from renewable resources. Other enterprises have neither agreements with renewable energy suppliers nor any renewable energy equipment.

As printing industry needs soft water one of the solutions is to use rainwater. Usually printing enterprises use water which has undergone softening.
Rainwater can be used without softening, but all particles should be removed before usage. None of enterprises use rainwater.

With implementation of environmental management systems (ISO 14001 and EMAS) enterprises actively inform customers about their contribution to more ecological product at the design stage. Customers can choose ecological paper and inks but it causes additional costs especially in an ecological inks case (Table 3). 
Enterprise sustainability index $\left(\mathrm{I}_{\mathrm{ESI}}\right)$ consists of three sub-indices: qualitative assessment ( $\left.\mathrm{I}_{\text {qual }}\right)$, quantitative assessment $\left(\mathrm{I}_{\text {quan }}\right)$ and level of actions towards sustainable development taken in environmental protection area $\left(\mathrm{I}_{\text {actions }}\right)$. This index calculated for $\mathrm{A}, \mathrm{B}$ and $\mathrm{C}$ enterprises shows that they
(Table 4) are at the basic sustainability level (index varies from 0.41 to 0.56 ).

In a separate sub-index some enterprises have achieved the progressive level - enterprises $\mathrm{B}$ and $\mathrm{C}$ in economical and social sub-indices. Enterprise $\mathrm{C}$ is intensively working in training its employees within one European Union project.

Table 4. Calculation of Enterprise Sustainabilty Index (I $I_{E S D}$

\begin{tabular}{|c|c|c|c|c|c|c|c|c||}
\hline \multirow{2}{*}{ Enterprises } & \multicolumn{2}{|c|}{$\begin{array}{c}\text { Economical } \\
\text { subindex }\end{array}$} & \multicolumn{2}{c|}{$\begin{array}{c}\text { Social } \\
\text { subindex }\end{array}$} & \multicolumn{2}{c|}{$\begin{array}{c}\text { Environmental } \\
\text { subindex }\end{array}$} & General index \\
\cline { 2 - 10 } & $\mathrm{I}_{\text {qual }}$ & $\mathrm{I}_{\text {quant }}$ & $\mathrm{I}_{\text {qual }}$ & $\mathrm{I}_{\text {quant }}$ & $\mathrm{I}_{\text {qual }}$ & $\mathrm{I}_{\text {quant }}$ & $\mathrm{I}_{\text {action }}$ & \\
\hline Enterprise A & 0.50 & 0.00 & 0.64 & 0.39 & 0.58 & 0.40 & 0.36 & 0.41 \\
\hline Enterprise B & 0.84 & 0.53 & 0.68 & 0.61 & 0.51 & 0.47 & 0.29 & 0.56 \\
\hline Enterprise C & 084 & 0 & 0.63 & 0.76 & 0.51 & 0.51 & 0.21 & 0.49 \\
\hline
\end{tabular}

\section{Conclusions}

Sustainability assessment of enterprises methodology was mainly oriented to the printing sector through modification of environmental indicators.

Enterprise sustainability index was extended by inclusion of actions and measures. Extended enterprises sustainability index does not give the static assessment only it indicates how the enterprise will develop in the near future.

Enterprise sustainability index shows that all three printing enterprises are at the basic sustainability level. Suggested environmental measures give guidelines to achieve sustainability in environmental protection. These measures may be: usage of rainwater, renewable energy, regeneration of used solvents and reduction of emissions of volatile organic compounds.

\section{References}

AMERICAN MANAGEMENT ASSOCIATION (AMA). 2007. A Sustainable Future: A Global Survey of Current Trends and Possibilities 2007-2017. 71 p.

DELOITTE and TOUCHE. 1992. Business strategy for sustainable development: leadership and accountability for the 90s. IISD.

DIAKAKI, C., GRIGOROUDIS, E., STABOULI, M. 2006. A risk assessment approach in selecting environmental performance indicators. Management of Environmental Quality. Vol. 17, no. 2, p. 126-139 http://dx.doi.org/10.1108/14777830610650456

ENROTH, M. 2006. Developing tools for sustainability management in the graphic arts industry. Doctoral thesis. Royal Institute of Technology, Stockholm. $129 \mathrm{p}$.

ENVIROVISE, 2004. Key environmental performance indicators in the printing sector, www.envirowise.gov.uk.
KINDERYTE, L., CIEGIS, R., STANISKIS, J.K. 2010. Assessment of Enterprise Performance for Efficient Sustainability. Transformations in Business and Economics. Kaunas Faculty of Humanities, Vilnius University. ISSN 1648 - 4460. p.104-118, Vol. 9, No 3(21).

KINDERYTÉ, L. 2010. Methodology of Sustainability Indicators Determination for Enterprise Assessment. Environmental research, engineering and management. Kaunas: Technologija, ISSN 1392- 1649, vol. 52 , no. 2 , p. $25-31$.

NARDO, M. et al. 2005. Handbook on constructing composite indicators: methodology and user guide, OECD Statistics Working Paper, 108 p. http://dx.doi.org/10.1787/533411815016

OECD. 2008. Handbook on Constructing Composite Indicators. Methodology and user guide, 160 p., ISBN 97892-64-04345-9.

POHJOLA, T. 2005. Applications of an environmental modelling system in the graphics industry and road haulage services. Implementing Environmental Management Accounting: Status and Challenges. Editors: Rikkardson, P.M; Bennett, M.; Bouma, J.J.; Schaltegger, S. Springer.

Reference Document on Best Available Techniques on Surface Treatment using Organic Solvents (BREF STS). 2007. 678 p.

STANIŠKIS， J.K.; ARBAČIAUSKAS， V. 2009. Sustainability Performance Indicators for Industrial Enterprise Management // Environmental Research, Engineering and Management. No. 2(48), P. 42-50.

SZÉKELY, F. and KNIRSCH, M. 2005. Leadership and Corporate Responsibility. Metrics for Sustainable Corporate Performance: Working Paper Series on Responsible Leadership and Sustainability, European School of Management and Technology, Berlin, $54 \mathrm{p}$.

VELEVA, V. and ELLENBECKER, M. 2000. A Proposal for Measuring Business Sustainability. Greener Management International. Iss. 31; p.101-121. 
VILUKSELA, P. 2009. Environmental indicators in heatset offset printing. In Proceedings of the 5th International Conference "EMAN 2009: Environmental Sustainable Development Indicators" 23-24 April, 2009, Prague, Czech Republic. Usti nad Labem: J.E.Purkyne University in Usti nad Labem.
MSc. Loreta Kinderytė - PhD student at the Institute of Environmental Engineering, Kaunas University of Technology.

Main research areas: environmental management systems, industrial ecology, sustainability assessment Address: $\quad$ K. Donelaičio str. 20,

Tel.: $\quad$ LT-44239 Kaunas,

E-mail: $\quad$ oloretaloreta@yahoo.com

\title{
Spaudos pramonès įmonių darnaus vystymosi vertinimas
}

\author{
Loreta Kinderytè \\ Aplinkos inžinerijos institutas, Kauno technologijos universitetas
}

(gauta 2011 m. rugsèjo mèn.; atiduota spaudai 2011 m. gruodžio mèn.)

Darnaus vystymosi koncepcija taikoma pasauliniu, nacionaliniu, regioniniu lygiais, taip pat ir imonès siekia vystytis darniai aplinkosaugos ir socialiniais aspektais. Taigi, auga darnaus vystymosi vertinimo ir igyvendinimo priemoniu poreikis. Populiariausia yra Pasaulinès veiksmingumo ataskaitu iniciatyva, kuri pateikia rekomendacijas darnaus vystymosi vertinimui skirtingiems sektoriams. Gairès yra parengtos logistikos, transportavimo, finansiniu paslaugų, kasybos ir metalo apdirbimo, telekomunikacijų ir kitoms šakoms. Vienas iš sektorių, kuriems nèra parengta rekomendaciju - tai leidybos ir poligrafijos sektorius. Straipsnio tikslas yra įvertinti spaustuviụ darnų vystymąsi. Šiam tikslui pasiekti iškelti uždaviniai: 1) pritaikyti darnaus vystymosi vertinimą spaustuvėms; 2) atlikti darnaus vystymosi vertinimą pasirinktose spaustuvėse ir 3) vertinamoms spaustuvèms pasiūlyti darnaus vystymosi priemones. Taikoma darnaus vystymosi vertinimo sistema susideda iš kokybinès ir kiekybinès dalies bei sudètinio indekso. Kokybinè ir kiekybinè dalys apjungiamos i patobulintą darnaus vystymosi indeksą. Imonès ịvertinamos priklausomai nuo pasiekimų ị besivystančias nedarniai, darniai ir pažangiai darniai. Apskaičiuoti darnaus vystymosi indeksai rodo, kad tiriamos spaustuvès vystosi darniai. Pagrindinès gerinimo sritys spaustuvėse yra aplinkai palankesnio popieriaus, dažų ir kitų cheminių medžiagu naudojimas, taršos lakiaisiais organiniais junginiais mažinimas, atsinaujinančios energijos naudojimas ir kt. Ši darnaus vystymosi vertinimo sistema gali būti pritaikyta ir kitiems sektoriams. 